\title{
IMPLEMENTASI METODE ELIMINASI GAUS PADA SISTEM INFORMASI INVESTASI EMAS MENGGUNAKAN OCTAVE
}

\author{
Dhimas Febri Sr, Eko Triono, Heru Anapranata \\ Teknik Informatika, Universitas Negeri Malang \\ heruanapranata240998@gmail.com
}

\begin{abstract}
Abstrak
Sistem persamaan linier merupakan salah satu model dan rumus pemecahan masalah yang banyak dijumpai dalam matematika. Sistem persamaan linear banyak digunakan dalam penyelesaian masalah contohnya dalam pembuatan sistem informasi. Persamaan linear tersebut dapat diselesaikan dengan mengimplementasikan metode gaus Untuk menghitung berapa jumlah x yang tidak dketahui dari persamaan dengan jumlah $\mathrm{n}$, membutuhkan waktu yang cukup lama sehiingga tidak efisien waktu dan sebagainya. Metode Gaus ini dilakukan dengan cara merubah atau mengkonversi persamaan yang di dapat ke dalam bentuk matriks augmentasi dan dioperasikan kembali menjadi matriks triangularisasi. Penerapan metode eliminasi gaus pada sistem informasi investasi emas ini, menunjukkan hasil perhitungan yang jika dibandingkan secara manual maupun dengan menggunakan software octave tidak ada perbedaan
\end{abstract}

Kata Kunci : Eliminasi Gauss, sistem informasi, Matlab

\section{Pendahuluan}

\subsection{Latar Belakang}

Komputer merupakan salah satu bentuk kecanggihan modern yang sangat berkembang dan penerapannya telah dimanfaatkan dalam berbagai bidang ilmu salah satunya dalam persoalan matematika di berbagai bidang ilmu pengetahuan seperti matematika dalam ilmu fisika, ilmu kima dan bahkan dalam rekayasa seperti jurusan teknik pada umumnya. Perenanan computer tersebut dapat mempercepat proses perhitungan tanpa membuat kesalahan.

Berbicara tentang perhitungan, dalam perkembangan ilmu matematika, maka banyak akan model model perhitungan matematika, salah satunya adalah sistem persamaan linier. Tidak hanya dalam kehidapan kecil ternayata pemanfaatan persamaan linier ini juga menjadi peranan.

Dalam berbagai bidang di kehidupan Sistem informasi ini banyak yang menerapkannya sebab dalam penerepannya sistem informasi dapat mempermudah manusia dalam melakukan pekerjaan ketika ia berada didalam suatu instansi maupun di dalam perusahaan. Untuk penerapan sistem informasi ini sangatlah beragam, salah satu contoh manfaatnya adalah dibuatnya sistem informasi investasi emas secara online

Pada sistem informasi investasi emas online ini menggunakan merode eliminasi gauss. Namun untuk menghitung berapa jumlah $\mathrm{x}$ persamaan yang kita tidak mengetahuinya yang mungkin sangat besar dan rumit, maka peranan computer sangat diperlukan agar dapat menghitung persamaan dari sistem informasi tersebut dengan cepat dan efisiensi waktu. Octave adalah aplikasi free and open source yang ditujukan untuk komputasi numerik linear maupun non linear. Octave sangat populer sebagai aplikasi alternatif dari MATLAB., Matlab dapat membantu penyelesaian sistem persamaan linier dengan menggunakan metode eliminasi Gauss[] Adapun tujuan dari penulisanj paper ini adalah untuk memberikan solusi atau pemecahan masalah dalam menangani kasus penyelesaian metode eliminasi gauus pada sebuah sistem infomasi yakni disini sistem informasi investasi emas dengan menggunakan octave alternatif dari Matlab.

\section{Dasar Teori Eliminasi Gauss}

Metode elimnasi Gauss adalah suatu cara mengoperasikan nilai-nilai di dalam matriks menjadi matriks yang lebih sederhana dan banyak digunakan dalam penyelesaian sistem persamaan linier.

Prosedur penyelesaian dari metode ini adalah dengan melakukan operasi baris menjadi matriks eselon-baris. Metode ini mengubah persamaan linear tersebut ke dalam matriks augmentasi dan mengoperasikannya. Sistem persamaan linier merupakan salah satu sistem persamaan yang terdiri dari sejumlah persamaan dan variabel yang berhingga. Untuk dapat menyelesaikan suatu sistem persamaan linier adalah mencari nilai-nilai variabelvariabel persamaan tersebut.

Metode eliminasi gauss digunakan untuk menyelesaikan sebuah sistem persamaan linier dengan mengubah SPL tersbut ke dalam bentuk sistem persaman linier berbentuk segitiga atas, yakni 
bentuk yang samas koefisien dibawah diagonal utamanya bernilai nol. Bentuk segitiga atas ini dapat diselesaikan dengan menggunakan subtitui(penyulihan) balik. Untuk mendapatkan bentuk SPL segitiga dari SPL yang diketahui, metode eliminasi Gauss menggunakan sejumlah operasi baris elementer(OBE):

1. Menukar posisi dua buah persamaan(dua baris matriks augmented)

2. Menambah sebuah persamaan (baris matriks augmented) dengan suatu kelipatan persamaanlain (baris lain)

Pada eliminasi Gauss terdapat dua metode untuk mencari penyelesaian persamaan [2] :

1. Metode langsung, yang mana terdiri dari metode eliminasi Gauss, eliminasi Gauss- Jordan, matriks invers dan metode dekomposisi LU.

2. Metode tak langsung, yang sering disebut juga metode iterasi. metode iterasi Jacobi dan metode iterasi Gauss-Seidel.

Adapun bentuk umum dari sistem persamaan linier adalah sebagai berikut [3] :

$$
\begin{gathered}
a_{11} x_{1}+a_{12} x_{2}+a_{13} x_{3} \ldots+a_{1 n} x_{n}=b_{1} \\
a_{21} x_{1}+a_{22} x_{2}+a_{23} x_{3} \ldots+a_{2 n} x_{n}=b_{2} \\
\vdots a_{n 1} x_{1}+a_{n 2} x_{2}+a_{n 3} x_{3} \ldots+a_{n n} x_{n}=b_{n}
\end{gathered}
$$

Penyelesaian dengan menggunakan metoda eliminasi Gauss terdiri dari beberapa tahap, yaitu:

1. Konversi persamaan linear ke dalam bentuk matriks teraugmentasi.adalah

$$
\begin{gathered}
x+2 y+z=6 \\
x+3 y+2 z=9 \\
2 x+y+2 z=12
\end{gathered}
$$

Maka, persamaan linear yang dikonversi ke dalam bentuk matriks teraugmentasi adalah:

$$
\left(\begin{array}{cccc}
1 & 2 & 1 & 6 \\
1 & 3 & 2 & 9 \\
2 & 1 & 2 & 12
\end{array}\right)
$$

2. Kemudian operasikan matriks yang telah dikonversi ke dalam bentuk matriks teraugmentasi dengan proses triangularisasi. Baris ke-2 pada matiks dikurangi dengan baris ke-1.

$$
\left(\begin{array}{llll}
1 & 2 & 1 & 6 \\
0 & 1 & 1 & 3 \\
2 & 1 & 2 & 1
\end{array}\right)
$$

Baris ke-3 dikurangi 2 kali baris ke-1:

$$
\left(\begin{array}{cccc}
1 & 2 & 1 & 6 \\
0 & 3 & 2 & 3 \\
0 & -3 & 0 & 0
\end{array}\right)
$$

Baris ke-3 ditambah 3 kali baris ke-2:

$$
\left(\begin{array}{llll}
1 & 1 & 1 & 6 \\
0 & 1 & 1 & 3 \\
0 & 0 & 3 & 9
\end{array}\right)
$$

Baris ke-3 ditambah 3 kali baris ke-3:

$$
\left(\begin{array}{llll}
1 & 2 & 1 & 6 \\
0 & 1 & 1 & 3 \\
0 & 0 & 1 & 3
\end{array}\right)
$$

3. Setelah terbentuk matriks baru dan diperoleh persamaan linear baru, yaitu

$$
\begin{gathered}
x+2 y+z=6 \\
y+z=3 \\
z=3
\end{gathered}
$$

4. Lakukan subsitusi balik maka diperoleh:

$$
\begin{aligned}
& y+z=3 \rightarrow y+3=3 \rightarrow y=0 \\
& x+2 y+=6 \rightarrow x+2(0)+3=3
\end{aligned}
$$

untuk lebih jelasnya dapat dilhat di diagram berikut

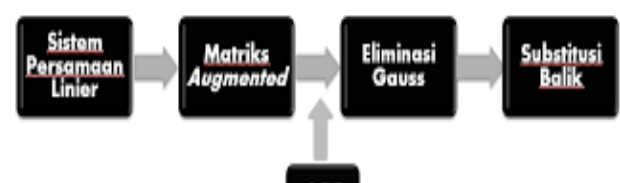

OBE

\section{Metode Gauss Menggunakan Octave}

Seperti yang telah dikatakan sebelumnya, metode gauss dilakukan dengan cara mengkonversikan dahulu persamaan linier yang di dapat, kemudian dari persamaan linier tersebut dikonversikan kedalam bentuk matriks Dalam perngujian kali ini yakni menggunakan rumus tersbut kedalam mat lab .

Octave merupakan aplikasi free and open source yang ditujukan untuk komputasi numerik linear maupun non linear. Octave sangat populer sebagai aplikasi alternatif dari MATLAB. Octave memiliki pustaka untuk melakukan manipulasi dan visualisasi data yang cukup lengkap. GNU Octave dikembangkan oleh GNU di bawah lisensi GNU General Public License. Octave pada dasarnya diciptakan bertujuan untuk menjadi kakas pembantu untuk mahasiswa tingkat dasar dalam memecahkan permasalahan di bidang rektor kimia yang ditulis oleh James B. Rawlings dari 
University of Wisconsin-Madison dan John G. Ekerdt dari University of Texas.

Komputasi, pemodelan, simulasi dan pembuatan protipe dari penerimaan data dan pengembangan aplikasi berbasis grafik dan pembuatan Graphical User Interface (GUI). Hal yang paling penting untuk diketahui, seluruh perhitungan yang dilakukan pada perangkat lunak ini dilakukan secara matematis dalam bentuk matriks.

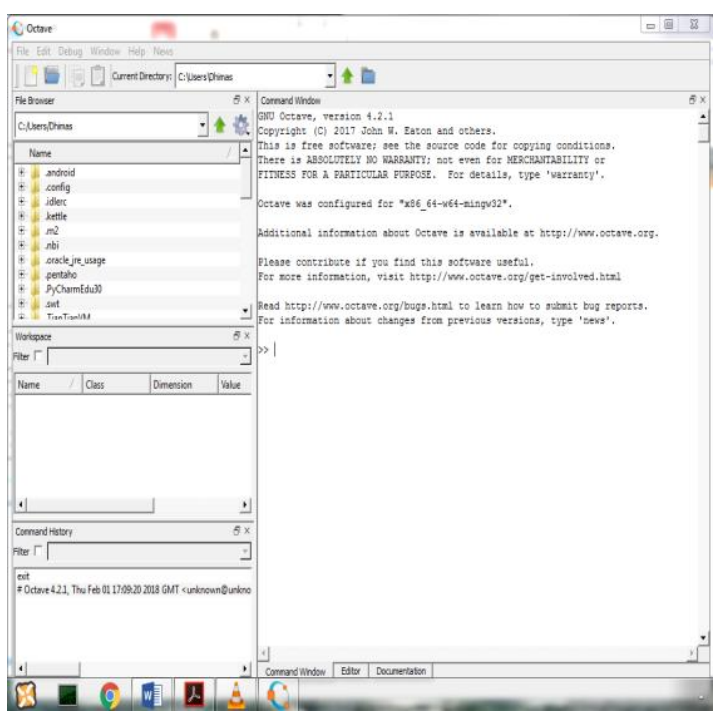

Gambar 1.Tampilan Awal Octave

\subsection{Implementasi dan Pembahasan Metode} Gauss

Adapun algoritma eleminasi Gauss adalah sebagai berikut:

1. Konversi sistem persamaan linear ke dalam bentuk matriks augmentasi.

2. Periksalah elemen-elemen pivot, apakah ada yang bernilai nol. Elemen-elemen pivot

adalah elemen-elemen yang menempati diagonal suatu matriks, tetapi jika ada

elemen diagonal yang bernilai 0, maka baris dimana elemen itu berada harus ditukar posisinya dengan baris yang dibawahnya sampai elemen diagbal matriks menjadi nol.

3. Lakukan proses triangularisasi.

4. Hitung nilai .

5. Lakukan subsitusi mundur untuk memperoleh nilai variabel yang dicari.

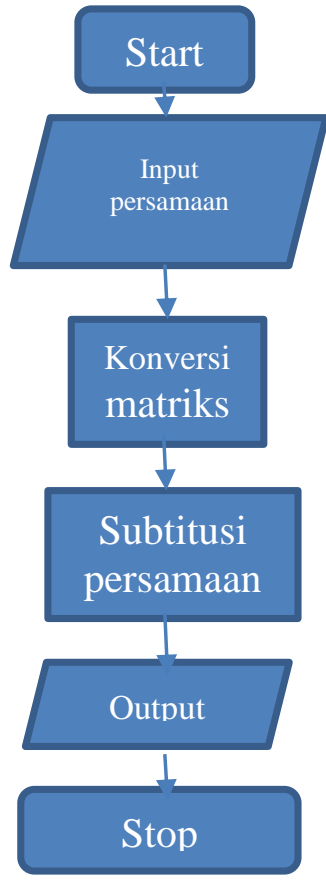

Gambar 2. Flowchart

Pada kasus permasalahan kali ini adalah suatu sistem informasi investasi emas yang menginginkan adanya fitur untuk menentukan berapa harga emas yang telah dbelinya pada waktu tertentu dilihat dari total pembelian emas yang ada dan jumlah batang emas yang dibeli pada waktu itu. Sehingga dimisalkan sebagai berikut:

\begin{tabular}{|c|c|c|c|}
\hline Ket & $\begin{array}{c}\text { Investor } \\
\mathrm{A}\end{array}$ & $\begin{array}{c}\text { Investor } \\
\mathrm{B}\end{array}$ & $\begin{array}{c}\text { Investor } \\
\mathrm{C}\end{array}$ \\
\hline Bulan 1 & $\mathrm{n}$ emas & $\mathrm{n}$ emas & $\mathrm{n}$ emas \\
\hline Bulan 2 & $\mathrm{n}$ emas & $\mathrm{n}$ emas & $\mathrm{n}$ emas \\
\hline Bulan3 & $\mathrm{n}$ emas & $\mathrm{n}$ emas & $\mathrm{n}$ emas \\
\hline Total & $\mathrm{n}$ & $\mathrm{n}$ & $\mathrm{n}$ \\
\hline
\end{tabular}

Bentuk umum persamaan liner adalah ax $1+a \times 2+a x 3$ $=\mathrm{b}$

- Symbol "a" dalam kasus ini adalah jumlah gram emas yang dibeli

- Symbol " $\mathrm{x}$ " berarti harga emas, $\mathrm{x} 1$ berarti harga emas pada bulan ke-1 dan seterusnya

- Symbol 'b" berarti total pembelian dari investor

Maka jika kita melihat data dari tabel dapat dijadikan persamaan sebagai berikut

1) $2 \times 1+\times 2+3 \times 3=33,5$

2) $x 1+x 2+3 \times 3=27,8$

3) $\times 1+2 \times 2+2 \times 3=28,3$

pada persamaan diatas dapat dianalogikan bahwa terdapat 3 investor emas yang sudah membeli masing- 
masing sejumlah gram emas. Investor pertama pada bulan pertama membeli 2 gram emas kemudian pada bulan kedua ia membeli 1 gram emas dan pada minggu ketiga ia membeli 3 gram emas dan dari situ muncul total pembelian yang sudah didapat selama 3 bulan terakhir. Namun investor tersebut ingin mengetahui kembali berapa harga emas per gramnya pada bulan tertentu. Dengan demikian hasil yang didapat dari eliminasi persamaan tersbut adalah nilai $\mathrm{x} 1, \mathrm{x} 2$,dan $\mathrm{x} 3$ atau harga emas pada bulan ke-1, ke-2 dan selanjutnya.

Dengan metode eliminasi gauss ini kita dapat menentukan nilai $\mathrm{x} 1, \mathrm{x} 2, \mathrm{x} 3$ atau berapa harga emas tiap bulan serta menganalisis harga yang berubah naik turun untuk mendapatkan rata rata harga emasnya.

Setelah mendapatkan persamaan tersebut, langkah awal untuk memulai metode persamaan gass adalah menkonversikan persamaan ke dalam bentuk matriks augmented. Matrriks augmented adalah matriks yang entrinya berisikan koefisien-koefisien SPL.

Beberapa penelitian telah difokuskan dalam sistem informasi jual beli. Sawitri (2009) mengembangkan sistem informasi jual beli yang dimiliki "Electrolux Au-thorized Service CV. Momentum Tek-nik". Sistem informasi ini mendoku-mentasikan data barang masuk dan barang keluar secara komputerisasi dan terintegrasi agar mempercepat kinerja perusahaan. Metode System Development Life Cycle (SDLC) yang digunakan, terdiri dari: perencanaan sistem hingga tahap perancangan sistem yang rinci, mencakup perancangan database, peran-cangan kontrol, perancangan input out-put, hingga teknologinya.Kelemahan sistem informasi ini adalah belum dapat diakses secara online.

Yudika (2009) mengembangkan sis-tem pelaporan produksi pengendalian mutu barangdi dalam sistem informasi jual beli pada PT.Socfindo Bangun Ban-dar. Sistem informasi yang dikembangkan adalah berbasis web. Di dalam sitem informasi ini, tenaga ahli harus mengecek mutu barang secara langsung dan meng-inputkan hasil pengecekan barang pada website yang telah disediakan.

Liker (2004) mengembangkan sistem kontrol produksi libah pada sistem infor-masi bank sampah. Limbah dan sampah disortir berdasarkan: kelebihan produksi, waktu tunggu, kelebihan pengolahan, kelebihan persediaan,dan cacat produksi.

Berdasarkan beberapa penelitian di atas, sistem informasi jual beli yang di-kembangkan dapat memonitor aktifitas jual beli sebuah perusahaan dengan mu-dah. Meskipun demikian, jumlah produksi barang masih diolah secara manual. Hal ini akanmemperlambat proses kon-trol barang. Padahal perusahaan menda-patkan keuntungan yang lebih tinggi jumlah jika perusahaan dengan cepat menganalisis penambahan produksi ber-dasarkan data statistika perusahaan ter-sebut Yudika (2009).

Salah satu algoritma yang memiliki waktu komputasi yang rendah adalah Fuz-zy. Fuzzy merupakan sistem inferensi yang dapat melakukan penalaran dengan prinsip seperti manusia berdasarkan naluri manusia. Di dalam Fuzzy,naluridimplementasikan kedalam perhitungan matema-tika dan statistika yang sederhana. Hal ini lah yang menyebabkan komputasi Fuzzy terbilang cukup rendah Sutoyo, et al (2011).

Berdasarkan penjelasan di atas dapat disimpulkan bahwa industri membutuh-kan proses kontrol produksi yang otomatis dan cepat. Sementara itu, Fuzzy merupa-kan salah satu algoritma yang dapat me-mecahkan suatu permasalahan dengan waktu komputasi yang rendah. Untuk itu, pada penelitian ini diusulkan Sistem Pen-dukung Keputusan Produksi berbasis Fuz-zy pada Sistem Informasi Jual Beli Online.

\subsection{Fuzzy}

Sistem pendukung keputusan/ decision support system (DSS) merupakan sebuah sistem yang secara otomatis mem-berikan sebuah keputusan atau rekomendasi terhadap suatu permasalahan. Salah satu algoritma yang dapat diterap-kan sebagai sistem pendukung keputusanadalah algoritma Fuzzy.

Fuzzy merupakan peningkatan dari logika Boolean yang berhadapan dengan konsep kebenaran sebagian. Saat logika klasi menyatakan bahwa segala hal dapat diekspresikan dalam istilah biner (0 atau 1), logika fuzzymenggantikan kebenaran Boolean dengan tingkat kebeneran(Suto-yo dkk, 2011).

Fuzzy sendiri merupakan sistem infe-rensi yang dapat melakukan penalaran dengan prinsip seperti manusia melaku-kan penalaran dengan nalurinya atau instingnya. Hal ini juga dapat diartikan bahwa fuzzy melogika suatu masalah un-tuk mendapatkan satu solusi Sutoyo, et al (2011).

Secara umum, tahapan - tahapan di dalam algoritma Fuzzy, terdiri dari:fuzzy-fikasi yaitu mencari nilai 1 atau 0 dalam aturan, pembentukan aturan (If ... Then), mesin inferensi yaitu mencari nilai max atau min, dan defuzzyfikasi untuk mencari nilai akhir Sutoyo, et al (2011).

Konsep Fuzzy berkembang menjadi tiga jenis, yaitu: metode Fuzzy-Sugeno, Fuzzy-Tsukamoto, dan Fuzzy-Hamdani. Dalam metode Tsukamoto memiliki taha-pan yaitu Fuzzyfikasi, pembentukan atur-anFuzzy, yang ketiga mencari nilai min atau mesin inferensi dan yang terakhir defuzzyfikasi yaitu pembentukan nilai akhir dengan menggunakan ratarata Sutoyo, et al (2011)..Dalam metode mamdani memiliki tahapan pertama fuzzyfikasi, pembentukan aturan, mesin inferensi yang menggunakan fungsimencari nilai min dan max, dan tahap defuzzyfikasi dengan menggunakan metode centroid Sutoyo, et al (2011).

Dalam metode Sugeno memiliki ta-hapan yaitu fuzzyfikasi, pembentukan aturan, inferensi menggunakan fungsi min, dan defuzzyfikasi 
menggunakan fungsi rata-rata Sutoyo, et al (2011).

\subsection{Sistem Informasi}

Sistem informasi ini merupakan sebu-ah gabungan antara sistem dan informasi. Sistem merupakan segala kumpulan hal atau elemen yang saling bekerjasama sehingga membentuk satu kesatuan untuk melaksanakan satu tujuan. Sedangkan informasi merupakan sebuah data yang telah di olah menjadi bentuk yang lebih berguna dan lebih berarti bagi yang menerimanya. Dari pengertian di atas sistem informasi bisa di simpulkan adalah sutau perkumpulan data yang terorganisa-si yang digunakan untuk suatu tujuan yang sama. Sistem informasi adalah suatu sistem di dalam suatu organisasi yang mempertemukan kebutuhan pengolahan transaksi, mendukung operasi, bersifat managerial dan kegiatan strategi dari su-atu organisasi dan menyediakan pihak luar tertentu dengan laporan-laporan yang diperlukan Laudon, et al (2007).

Sistem informasi erat hubungannya dengan Teknologi Informasi dan aktivitas orang yang menggunakan teknologi itu untuk mendukung operasi dan manaje-men.

Sistem informasi dapat di kategorikan menjadi 4 bagian yaitu Sistem informasi manajemen, sistem pendukung keputus-an, sistem informasi eksekutif dan sistem pemrosesan transaksi Laudon, et al ( 2007).

Penerapan sistem informasi sangatlah luas dan hampir di semua bidang kehi-dupan terdapat sistem informasi di da-lamnya, misalnya yaitu sistem informasi yang digunakan untuk memperkirakan banyaknya jumlah barang yang harus diproduksi. Penerapan tersebut merupa-kan penerapan sistem informasi di bidang transaksi.

\section{METODE}

\subsection{Data Penelitian}

Data uji coba yang digunakan adalah Lima puluh datapenjualan mobil bekas pada mobilhandal.com dengan dua tipe mobil yang berbeda.

\subsection{Pengembangan Fuzzy sebagai Sistem Pendukung Keputusan Produksi}

Pada penelitian ini, diusulkan sistem pendukung keputusan produksi berbasis Fuzzy pada sistem informasi jual beli online.Jumlah produksi yang dimaksud dalam penelitian ini adalah jumlah pembelian mobil yang harus dilakukan oleh pihak Mobilhandal.com sebagai tambah-an stok barang.

Jumlah pembelian mobil diperoleh secara otomatis berdasarkan perbanding-an jumlah stok yang tersedia dan jumlah permintaan yang terjadi dalam satu bu-lan. Stok atau persediaan barang dan jumlah penjualan dikomputasi dengan algoritma Fuzzysetiap satu bulan satu kali. Secara umum, tahapan algoritma Fuzzy yang diterapkan pada penelitian ini, ditunjukkan pada Gambar 1.

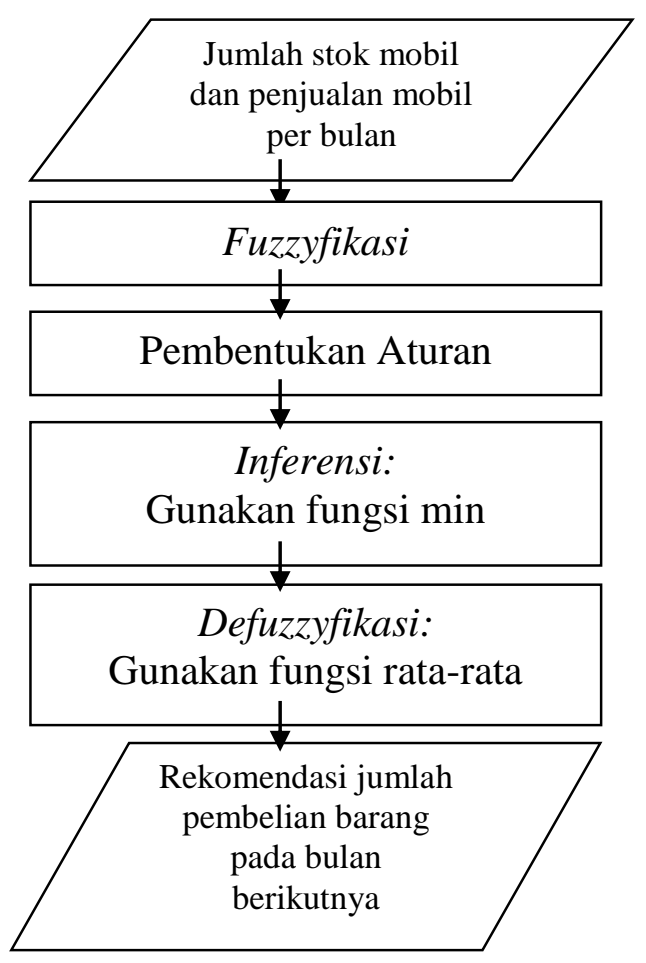

Gambar 1. Sistem Pendukung Keputusan Produksi Berbasis Fuzzy

Pada tahap awal dilakukan fuzzyfikasi terhadap variabel stok mobil dan jumlahpenjualan mobil. Pada tahap fuzzyfikasi, dilakukan pengelompokan variabel ke dalam beberapa kategori yang dimplementasikan dalam pembentukan fungsi keanggotaan. Grafik fungsi keanggotaan stok mobil ditunjukkan pada Gambar 2. Sedangkan Grafik fungsi keanggotaan penjualan mobil ditunjukkan pada Gam-bar 3.

Berdasarkan Gambar 2, stok/persedi-aan mobildibagi menjadi dua kategori di dalamnya yaitu persediaan kondisi rendah dan persediaan kondisi tinggi. Fungsi ke-anggotaan stok rendah ditunjukkan pada Persamaan 1. Sementara itu, fungsi keanggotaan stok tinggi ditunjukkan pada Persamaan 2.

$$
\begin{aligned}
& \mu_{\text {stok }}(\text { rendah })= \begin{cases}1 & s<3 \\
\frac{s}{6} & 3 \leq s \leq 6 \\
0 & s>6\end{cases} \\
& \mu_{\text {stok }}(\text { tinggi })= \begin{cases}\frac{1}{s} & s>6 \\
\frac{1}{10} & 3 \leq s \leq 6 \\
0 & s<3\end{cases}
\end{aligned}
$$


Pada Persamaan 1 dan 2, $\mu_{\text {stok }}($ tinggi) dan $\mu_{\text {stok }}$ (rendah) merupakan nilai kecenderungan stok pada kategori tinggi dan kategori rendah. Sedangkan s adalah nilai stok yang ada pada dealer.

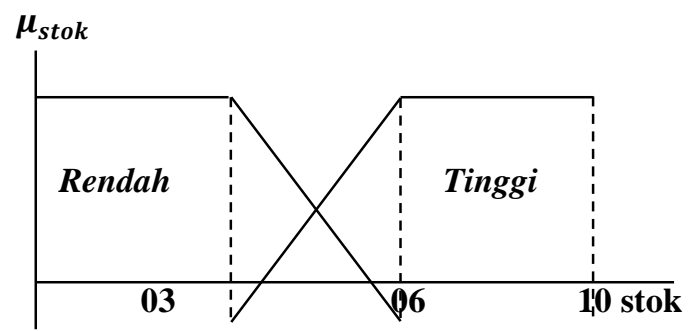

Gambar 2. Grafik Fungsi Keanggotaan Stok Mobil

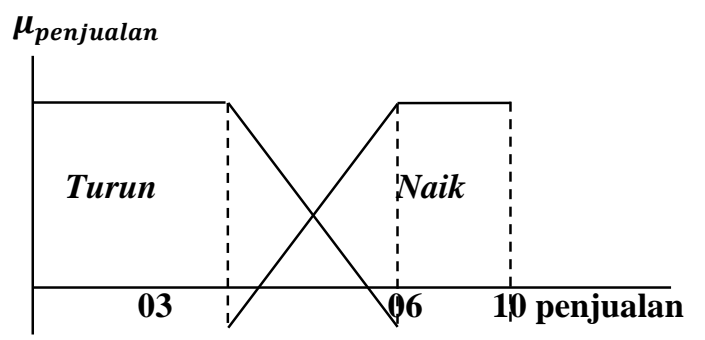

Gambar 3. Grafik Fungsi Keanggotaan Penjualan Mobil

Berdasarkan Gambar 3, jumlah pen-jualan mobildibagi menjadi dua kategori di dalamnya yaitu jumlah penjualan naik dan jumlah penjualan turun. Fungsi ke-anggotaan penjualan turun ditunjukkan pada Persamaan 1. Sementara itu, fungsi keanggotaan penjualan naik ditunjukkan pada Persamaan 2.

$$
\begin{aligned}
& \mu_{\text {penjualan }} \text { (turun) }= \begin{cases}1 & p<3 \\
\frac{p}{6} & 3 \leq p \leq 6 \\
0 & p>6\end{cases} \\
& \mu_{\text {penjualan }}(\text { naik })=\left\{\begin{array}{cc}
1 & p>6 \\
\frac{p}{10} & 3 \leq p \leq 6 \\
0 & p<3
\end{array}\right.
\end{aligned}
$$

Berdasarkan Persamaan 3 dan 4,

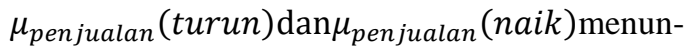
jukkan nilai kecenderungan penjualandalam kategori naik dan kategori rendah. Sedangkan $j$ adalah jumlah penjualan suatu mobil dalam satu bulan.

Tahap selanjutnya adalah pembentukan aturan. Karena terdapat dua variabel penentu hasil rekomendasi, maka jumlah maksimum aturan yang dapat dibuat ditunjukkan pada Persamaan 5.

$$
m=2^{n}
$$

Dimana $\mathrm{n}$ adalah jumlah variabel penen-tu dan $\mathrm{m}$ adalah $m$ adalah jumlah aturan mak-simum yang dapat dibuat.Berdasarkan Persa-maan 5, maka pada penelitian ini dibuat empat aturan. Adapun aturan

\begin{tabular}{|c|c|}
\hline $\begin{array}{c}\text { Kode } \\
\text { Aturan }\end{array}$ & Aturan \\
\hline [R1] & $\begin{array}{l}\text { IF penjualannaik dan stok rendah } \\
\text { THEN produksi }=\text { stok }+16 .\end{array}$ \\
\hline [R2] & $\begin{array}{l}\text { IF penjualan turun dan stok tinggi } \\
\text { THEN berhenti produksi. }\end{array}$ \\
\hline [R3] & $\begin{array}{l}\text { IF penjualan naik dan stok tinggi } \\
\text { THEN produksi }=\text { stok }+8\end{array}$ \\
\hline [R4] & $\begin{array}{l}\text { IF penjualan turun dan stok rendah } \\
\text { THEN produksi }=\text { stok }+5\end{array}$ \\
\hline
\end{tabular}
yang dibentuk ditunjukkan pada Tabel 1.

Tabel 1.Aturan Penambahan Produksi

Berdasarkan Tabel 1,rekomendasi jumlah produksi pada aturan ke $i\left(z_{i}\right)$ di-dapat dengan menambah stok dengan $z$ jumlah mobil yang harus ditambahkan berdasarkan aturan ke $i$. Sehingga nilai $\mathrm{z}_{1}, \mathrm{z}_{2}, \mathrm{z}_{3}$, dan $\mathrm{z}_{4}$ dapat dirumuskan pada Tabel 2.

Tabel 2.Penetapan Nilai $z$

\begin{tabular}{cc}
\hline $\begin{array}{c}\text { Kode } \\
\text { Aturan }\end{array}$ & $\begin{array}{c}\text { Jumlah Mobil yang harus } \\
\text { Ditambahkan } \\
(\mathbf{z})\end{array}$ \\
\hline$[\mathrm{R} 1]$ & $Z_{1}=50$ \\
\hline$[\mathrm{R} 2]$ & $Z_{2}=0$ \\
\hline$[\mathrm{R} 3]$ & $Z_{3}=20$ \\
\hline$[\mathrm{R} 4]$ & $Z_{4}=20$ \\
\hline
\end{tabular}

Langkah selanjutnya adalah inferensi dengan fungsi min. Adapun fungsi infe-rensi pada aturan satu sampai empat seca-ra berturut-turut ditunjukkan pada Persa-maan 6-9.

$$
\begin{array}{r}
\alpha_{1}=\min \left(\mu _ { \text { penjualan } } \left(\text { naik, } \mu_{\text {stok }}(\text { rendah })(6)\right.\right. \\
\alpha_{2}=\min \left(\mu _ { \text { penjualan } } \left(\text { turun, } \mu_{\text {stok }}(\text { tinggi })\right.\right. \\
\alpha_{3}=\text { min }\left(\mu _ { \text { penjualan } } \left(\text { naik, } \mu_{\text {stok }}(\text { tinggi })(8)\right.\right. \\
\alpha_{4}=\min \left(\mu _ { \text { penjualan } } \left(\text { naik, } \mu_{\text {stok }}(\text { rendah })\right.\right.
\end{array}
$$

Pada tahap terakhir dilakukan defuz-zyfikasi. Setelah mendapatkan nilai infe-rensi, selanjutnya hasil rekomendasi mobil $\left(z^{*}\right)$ akan di proses dengan fungsi rata-ratayang ditunjukkan pada Persama-an 10 .

$$
z^{*}=\frac{\sum_{1}^{m} \alpha_{i} \cdot z_{i}}{\sum_{1}^{m} \alpha_{i}}
$$

dimana $m$ adalah aturan maksimum yang dibuat, $z^{*}$ adalah hasil rekomendasi.ziadalah jumlah mobil yang harus ditam-bahkan berdasarkan aturan ke $i . \alpha_{l}$ adalah nilai inferensi pada aturan ke $i$.

\subsection{Uji Coba Waktu Komputasi Fuzzy}

Setelah mengembangkan sistem pen-dukung keputusan produksi berbasis Fuz-zy pada sistem 
informasi jual beli online, dilakukan pengujian performa kecepatan Fuzzy dalam menghasilkan keputusan. Pengujian dilakukan di dua spesifikasi laptop yang ditunjukkan pada Tabel 3.

\section{Tabel 3.Spesifikasi Pengujian}

\begin{tabular}{cl}
\hline $\begin{array}{c}\text { Kode } \\
\text { Laptop }\end{array}$ & \multicolumn{1}{c}{ Spesifikasi } \\
\hline & Sistem Operasi: Windows 7 Ultimate \\
Laptop 1 & 32-bit \\
& Processor:Pentium(R)Dual-Core \\
& CPU@ 1.00Ghz \\
\hline & Sistem Operasi: Windows 7 Ultimate \\
Laptop 2 & 32-bit \\
& Processor:Core i5 @ 2.5Ghz \\
\hline
\end{tabular}

\section{HASIL}

\subsection{DeskripsiSistem Informasi Jual Beli Mobil Bekas}

Pada sistem informasi yang dikem-bangkan, terdapat dua pengguna, pembeli dan admin. Halaman pertama yang diak-ses pengguna adalah halaman utama yang ditunjukkan pada Gambar 4.

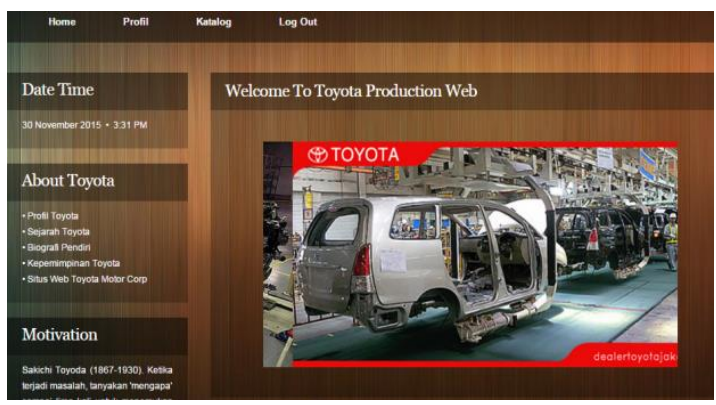

Gambar 4.Halaman Utama Sistem Informasi Jual Beli Mobil Bekas

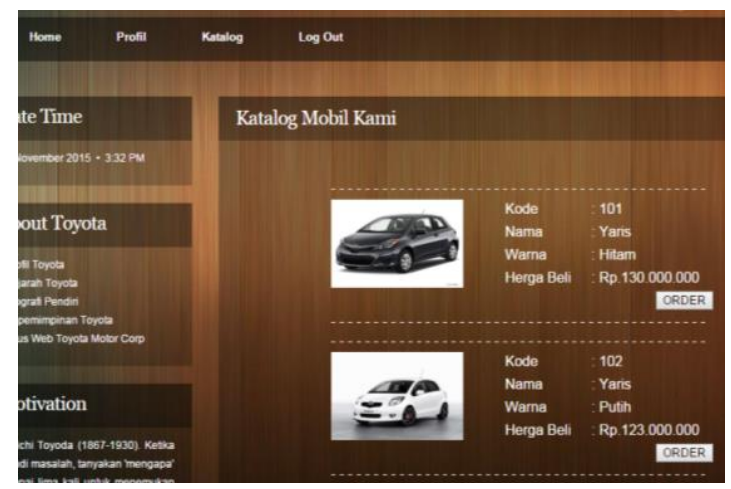

Gambar 5.Halaman Katalog Mobil

Pada halaman utama terdapat link untuk katalog mobil yang dijual yang ditunjukkan pada Gambar 5.Jika pembeli hendak melakukan transaksi pembelian mobil, user cukup menekan tombol order.Selanjutnya user dapat menentukan jum-lah yang dipesan pada halaman pemesan-an mobil yang ditunjukkan pada Gambar 6 (a).Pembeli juga dapat mencetak struk pembelian yang ditunjukkan pada Gambar 6 (b). Data-data mobil yang ada pada halaman katalog diinputkan oleh admin. Halaman input data mobil ditunjukkan pada Gambar 7.

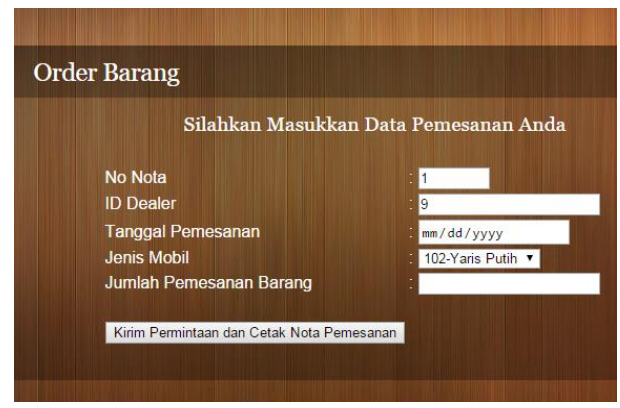

(a)

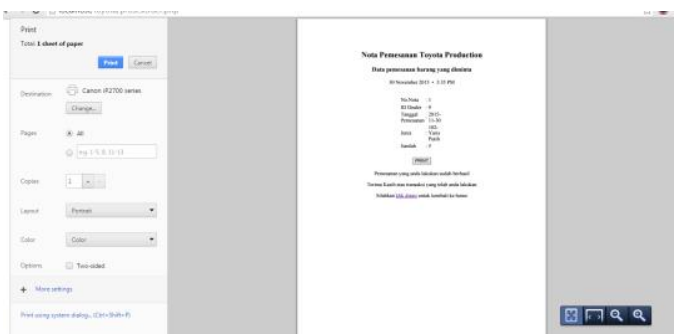

(b)

Gambar 6.Halaman Pemesanan (a) Input Pesanan (b) Cetak Pesanan

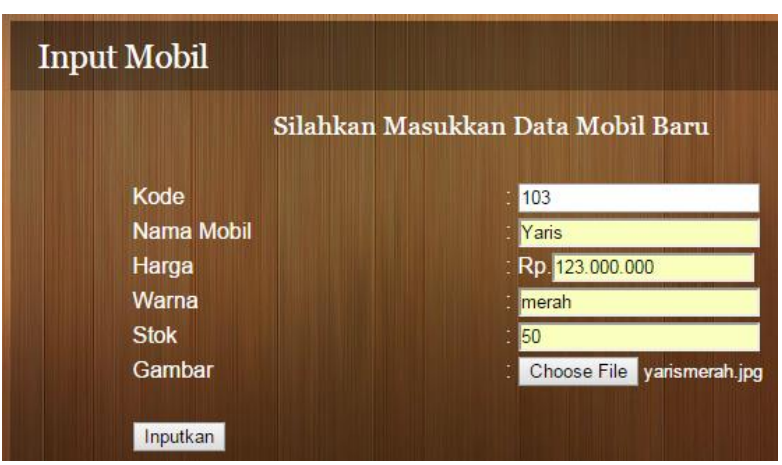

(a)

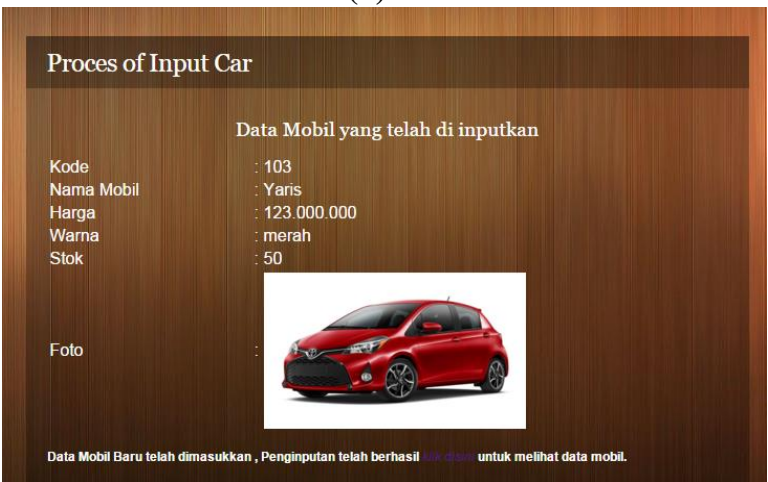

(b)

Gambar 7.Halaman Input Data Mobil (a) Formulir Input Data Mobil (b) Hasil Keluaran Data Mobil 
Selain dapat menginputkan data mo-bil, admin juga dapat memberi verifikasi pemesanan yang dapat ditunjukkan pada Gambar 8.

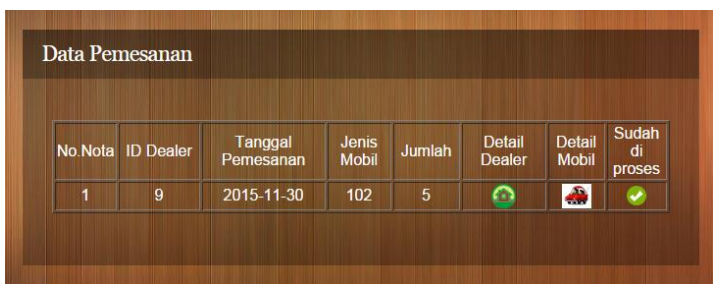

Gambar 8.Halaman Verifikasi Pemesanan

\subsection{Deskripsi DSS Berbasis Fuzzy}

Selain dapat mengelola proses jual beli, sistem informasi yang dikembang-kan juga dapat memberikan estimasi jum-lah mobil yang seharusnya dibeli pada bulan berikutnya. Rekomendasi yang diproses menggunakan algoritma Fuzzy ini ditunjukkan pada Gambar 9.

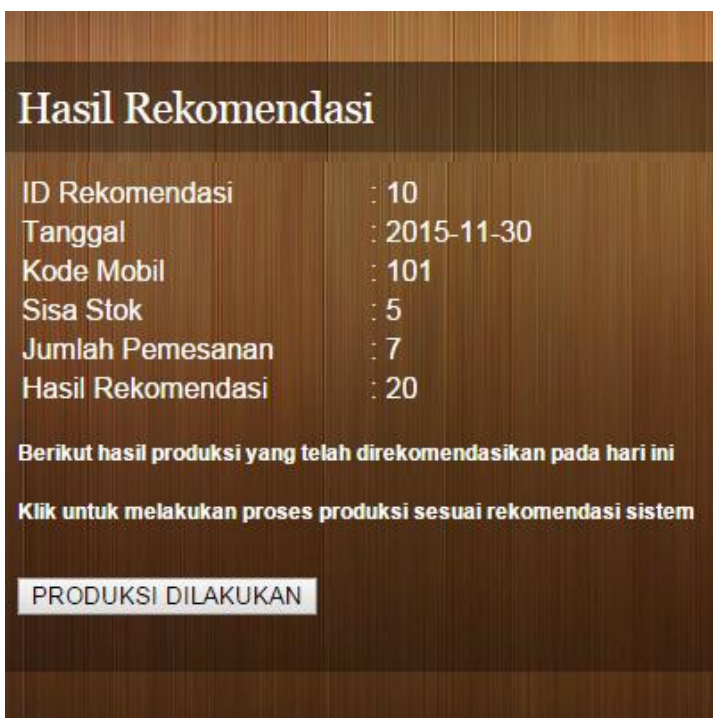

Gambar 9.Halaman rekomedasi

Pada Gambar 9, halaman rekomen-dasi menampilkan kode mobil, stok yang tersedia, dan jumlah pemesanan. Selan-jutnya stok yang tersedia dan jumlah pemesanan pada bulan tersebut dikomputasi menggunakan Fuzzy, sehingga meng-hasilkan keluaran jumlah mobil yang harus ditambahkan oleh pihak handal-mobil.com. Jika rekomendasi pihak per-usahaan telah menyetujui dan telah mem-beli mobil sejumlah hasil rekomendasi, admin cukup menekan tombol "produksi dilakukan" dan data jumlah mobil akan bertambah secara otomatis. Sebaliknya, jika perusahaan tidak menyetujui rekomendasi yang diberikan oleh sistem, maka admin tidak perlu menekan tombol "produksi dilakukan".

\subsection{Pengujian DSS berbasis Fuzzy}

Pada penelitian ini, dilakukan uji coba kecepatan algoritma Fuzzy dalam mem-berikan rekomendasi.
Uji coba dilakukan pada dua laptop dengan spesifikasi yang telah ditunjukkan pada Tabel 3 . Setiap laptop diuji coba sebanyak lima kali. Adapun hasil percobaan waktu komputasi sistem pendukung keputusan yang dikem-bangkan ditunjukkan pada Tabel 4.

Tabel 4.Pengujian Waktu Komputasi

\begin{tabular}{ccc}
\hline \multirow{2}{*}{$\begin{array}{c}\text { Uji } \\
\text { Coba }\end{array}$} & \multicolumn{2}{c}{ Kecepatan Load Fuzzy } \\
\cline { 2 - 3 } Laptop 1 & Laptop 2 \\
\hline 1 & 00.00 .01 .76 & 00.00 .00 .81 \\
\hline 2 & 00.00 .01 .81 & 00.00 .01 .80 \\
\hline 3 & 00.00 .01 .90 & 00.00 .01 .80 \\
\hline 4 & 00.00 .02 .18 & 00.00 .01 .85 \\
\hline 5 & 00.00 .02 .22 & 00.00 .01 .87 \\
\hline Rata-rata & $\mathbf{0 0 . 0 0 . 0 1 . 9 7}$ & $\mathbf{0 0 . 0 0 . 0 1 . 6 2}$ \\
\hline Rerata Total & \multicolumn{2}{c}{$\mathbf{0 0 . 0 0 . 0 1 . 7 9}$} \\
\hline
\end{tabular}

Berdasarkan hasil pengujian, rata-rata waktu komputasi pada kedua laptop adalah 1,79 detik.

\section{PEMBAHASAN}

Berdasarkan hasil pengujian waktu komputasi, laptop kedua lebih cepat di-bandingkan laptop pertama. Hal ini dise-babkan oleh perbedaan kecepatan prose-sor. Seperti yang telah dijelaskan, laptop pertama memiliki kecepatan prosesor 1.00 $\mathrm{GHz}$ dengan tipe prosesor Pentium Dual Core. Sedangkan laptop kedua me-miliki kecepatan prosesor $2.5 \mathrm{GHz}$ dengan tipe Core i5. Selain itu, semakin banyak data, semakin lama pula waktu komputasinya. Bagaimanapun, rata-rata waktu komputasi tidak mencapai lebih dari dua detik.

\section{KESIMPULAN}

Hasil pengujian waktu komputasi sistem pendukung keputusan produksi berbasis Fuzzy menunjukkan rata-rata waktu komputasi sebesar 1,79 detik. Ber-dasarkan hasil tersebut, dapat disimpulkan bahwa algoritma Fuzzy memberikan rekomendasi jumlah produksi secara cepat. Bagaimanapun kecepatan algorit-ma ini tetap dipengaruhi oleh jumlah data dan kecepatan prosesor. Selain itu, nilai $z_{i}$ dan batas fungsi keanggotaan masih dica-ri secara manual. Untuk itu, pencarian nilai $z_{i}$ dan batas fungsi keanggotaandapat dijadikan untuk penelitian lebih lanjut.

\section{Daftar Pustaka :}

Laudon, Kenneth C.; Laudon, Jane P. 2007.Sistem Informasi Manajemen. Palgrave, Basingstoke.

Liker, Jeffrey K. 2004.The Toyota Way. Amerika: Mc Grawhill.

Sawitri, Dewi. 2009. Perancangan Informasi Manajemen Persediaan Barang "Electrolux 
Authorized Service CV Momentum Teknik". Universitas Gunadarma.

Sutoyo dkk. 2011. Kecerdasan Buatan. Yogjakarta: Andi.

Yudika, Dirka. 2009. Sistem Informasi Produksi dan Pengendalian Mutu CPO Di PT.Socfindo Bangun Bandar. Universitas Sumatra Utara 